\title{
РОЛЬ І МІСЦЕ АРТ-ТЕРАПІЇ У ФОРМУВАННІ КОМУНІКАТИВНИХ НАВИЧОК ДІТЕЙ 3 ОСОБЛИВИМИ ПОТРЕБАМИ
}

У статті теоретично обтрунтовано результати експериментальної перевірки системи роботи з формування комунікативних навичок дітей із особливими потребами засобами арттерапії, які реалізуються в умовах навчальних закладів та визначають мету, принципи, та зміст, форми в роботі дефектологів.

У змісті статті доводиться, щзо комунікативні навички є засобом здійснення мовленнєвого спілкування. Виявлено, щзо комунікативні навички й спілкування становлять багатоплановий прочес, потрібний для організації контактів між людьми в ході спільної діяльності. З'ясовано, що представлені техніки арт-терапії при умові використання їх у корекційно-розвивальній роботи з дітьми з особливими потребами сприятливо впливають на формування у них комунікативних навичок.

Ключові слова: діти з особливими потребами, арт-терапія, техніки арт-терапії, комунікативні навички.

В статье теоретически обоснованы результаты экспериментальной проверки системы работы по формированию коммуникативных навыков детей с особыми потребностями средствами 
арт-терапии, которые реализуются в условиях учебных заведений и определяют цель, принципы, $u$ содержание, формы в работе дефектологов.

В содержании статьи доказывается, что коммуникативные навыки являются средством осуществления речевого общения. Выявлено, что коммуникативные навыки и общение составляют многоплановый процесс, необходимый для организачии контактов между людьми в ходе совместной деятельности. Выяснено, что представленные техники арт-терапии при условии использования их в коррекционно-развивающей работе с детьми с особыми потребностями благоприятно влияют на формирование у них коммуникативных навыков.

Ключевые слова: дети с особыми потребностями, арт-терапия, техники арт-терапии, коммуникативные навыки.

Постановка проблеми. Сучасна ситуація в освіті є непростою. Неухильно зростає кількість відхилень у розвитку дітей. Багато $є$ дітей зі складними аномаліями органічного походження, також відчутне зростання і кількості дітей із психогенними порушеннями, які проявляються в аутизації, агресивності, порушенні поведінки й діяльності, тривожно-фобічних розладах, перекрученні процесів соціалізації. Фактично допомоги потребує дуже численна категорія дітей.

Міжособистісні стосунки дають основну почуттям, переживанням; дозволяють виявити емоційний відгук, розвинути механізми саморегуляції (самоконтролю). Уповільнення темпів і якісна своєрідність емоційно-особистісного розвитку, несформованість вікових форм спілкування, нерозвиненість його структурних компонентів пояснюють труднощі в спілкуванні 3 оточуючими людьми в дітей 3 особливими потребами. Питання подолання відставання дітей 3 особливими потребами у розвитку комунікативної діяльності й виведення їх на рівень оптимально реалізованих вікових можливостей дуже актуальна.

Аналіз останніх досліджень і публікацій. Проблема розвитку комунікативних навичок стала однією 3 самих пріоритетних у психолого-педагогічній науці. У науковій літературі досліджено окремі питання формування комунікативних навичок: особливості їх розвитку у дітей з особливими потребами вивчали Л. Савчук, С. Тарасюк (у школярів із ЗПР), Л. Ханзерук (у дітей з ДЦП), І. Гудим, I. Некрасова (у слабозорих). У наукових працях дослідників, які працювали у галузі спеціальної психології та корекційної педагогіки розкрито роль спілкування у становленні особистості розумово відсталої дитини (Л. Виготський, В. Варянен, Л. Кузьмайте, Н. Коломинський); описано чинники, які перешкоджають спілкуванню (Н. Москоленко); з'ясовано психологічні умови формування соціальнокомунікативної активності (С. Карпенчук, Н. Москоленко, Т. Пороцька, С. Тарасюк). Психологічні основи формування комунікативної активності розкриваються в роботах Л. Божович, Л. Виготського, П. Гальперіна, Л. Герасимової, В. Давидова, І. Дубровіної, І. Кона, К. Корнілова, О. Леонтьєва, В. Мухіної, В. Петровського, С. Рубінштейна, А. Арушанової, Я. Коломінського, О. Лісіної, В. Мухіної, В. Селіванова, Д. Ельконіна та ін.

Формулювання цілей статті. Мета статті полягає у тоеретичному обгрунтуванні ролі та місця арт-терапії у формуванні комунікативних навичок дітей з особливими потребами.

Виклад основного матеріалу дослідження. Незважаючи на різні трактування поняття «комунікативні навички», які зустрічаються в психолого-педагогічній літературі, їх поєднує практична спрямованість і вказівка на ті або інші компоненти спілкування: уміння своєчасно вступати в діалог і завершувати його, використовуючи мовленнєві обороти для встановлення контакту, підтримувати й завершувати діалог, уміння відповідати на запитання, ставити запитання в ході діалогу, слухати співрозмовника. У дітей з особливими потребами є досить типові проблеми, які зустрічаються найбільше часто в колективі однолітків. До них відносяться різного роду обмеження, сором за свою хворобу, почуття неповноцінності, неприйняття колективом дітей з нормативним розвитком. Упертість і нетерплячість, невміння контролювати свою поведінку найчастіше можуть призводити до конфліктів з однолітками й труднощів навчального характеру. Егоцентризм і впертість також приводять до конфліктів і сварок з товаришами. Невпевність у собі, вразливість, нерішучість дітям 3 особливими потребами в більшості випадків заважають формуванню дружніх стосунків 3 колективом, вони соромляться відповідати перед іншими дітьми [1, с. 137]. Поведінка таких дітей відрізняється підвищеною дратівливістю, нестриманістю; характерною для дітей є схильність до конфліктів 3 оточуючими, поєднується 3 надмірною стомлюваністю, нестерпністю психічної напруження. Настрій у них украй нестійкий, іноді проявляється з відтінком невдоволення, роздратування. Ці діти вимагають до себе постійної уваги, схвалення своїх дій; а якщо цього немає, то виникають спалахи невдоволення, гніву, які звичайно закінчуються сльозами. У них найбільш часто спостерігаються афективно-збудливі форми поведінки, однак у новій для них обстановці може, навпаки, проявлятися підвищена загальмованість [1, с. 137].

Випуск 11, 2018 Збірник наукових праць РДГУ. 
Часто діти із нормативним розвитком не розуміють мотивів поведінки однолітків 3 обмеженими можливостями, не помічають недоліків одногрупників. А ось агресія, нерозуміння гумору, зайва розважливість, інфантилізм дітей з порушеннями звертають на себе увагу однолітків. Г. Колесникова вказує, що як правило, причиною конфліктів між дошкільниками виступають труднощі взаєморозуміння. Дитині дошкільного віку складно проаналізувати причини агресивної поведінки свого ровесника з тим або іншим порушенням. Але це не заважає зробити висновок про те, що $з$ ним краще менше спілкуватися, що він дивний, «не такий, як я». Успіх у колективі залежить від ступеня відповідності дитини загальним вимогам, прийнятим у даному товаристві [1, с. 138]. У дошкільників 3 особливими потребами часто відзначаються неправильні взаємини 3 колективом, що несприятливо позначається на подальшому розвитку особистості. Так само, якщо потреба стосунків таких дітей з однолітками не реалізовується, можуть виникнути різні афективні реакції, які проявляються у формі вразливості, озлобленості, замкнутості, іноді агресивної поведінки [1, с. 138]. Г. Колесникова вважає, що витримані труднощі у розвитку комунікативних навичок у дітей із особливими потребами сприяють розвитку таких рис особистості, як боязкість, сором'язливість, невміння постояти за свої інтереси. Це поєднується 3 підвищеною чутливістю, вразливістю, замкнутістю [1, с. 139-140].

Техніки арт-терапії $є$ одним 3 найефективніших елементів психологічної корекції й реабілітації. На сьогоднішній день закордонними й вітчизняними фахівцями накопичений багатий досвід застосування арт-терапії в роботі з дітьми, у тому числі з особливими потребами. Даний метод здобуває особливу актуальність в умовах сучасної системи державної освітньої системи. I. П'ятницька-Позднякова [4] та T. Росік [5] стверджують, що арт-терапевтична робота здобуває особливу цінність у роботі з дітьми, які мають певні труднощі у вербалізації своїх переживань, зокрема через мовленнєві дефекти, аутизм або інші форми порушень, а також складності цих переживань i ïx «невимовності». Л. Полторак вважає, що для них творча діяльність стає альтернативним «мовленням», більш точним і виразним, ніж слова. Особливі діти в більшості випадків мають труднощі у вербалізації своїх проблем і переживань, позаяк невербальна експресія для них більш природня. Сказане вище стає винятково важливим у роботі з дітьми із особливими потребами, адже їхня поведінка більш спонтанна й вони менш здатні до рефлексії своїх дій і вчинків, a їх переживання реалізовуються через художнє зображення більш безпосередньо [3, с. 90]. На думку О. Титаренко, такий «продукт» простий для сприйняття й аналізу [8]. I. Сусаніна 3 метою попередження дезадаптації, соціальної депривації, дітям із особливими потребами радить приділяти особливу увагу та турботу. Сьогодні використовують методи арт-терапії, що сприяе оздоровленню, гармонізації розвитку особистості дитини та іiї інтеграції в суспільство [7, с. 26]. Л. Підлипишина зазначає, що арт-терапія $є$ одним 3 найсучасніших підходів до корекції та реабілітації дітей 3 особливими потребами. Арт-терапія (терапія мистецтвом) - один з методів психологічної роботи, що використовує можливості мистецтва для досягнення позитивних змін в інтелектуальному, емоційному й особистісному розвитку людини [2, с. 11].

За словами О. Титаренко, арт-терапія володіє очевидними перевагами перед іншими заснованими виключно на вербальній комунікації - формами психотерапевтичної роботи, а саме [8, с. 14]:

практично кожна дитина 3 особливими потребами (незалежно від свого віку, культурного досвіду, соціального стану) може брати участь в арт-терапевтичній роботі, яка не вимагає від неї яких- небудь здібностей до образотворчої діяльності або інших художніх навичок;

творча діяльність $є$ могутнім засобом формування комунікативних навичок, що сприяє зближенню людей, своєрідним «мостом» між фахівцем і дитиною. Це особливо цінно в ситуаціях взаємного відчуження, при труднощів налагодження контактів з дітьми, у спілкуванні з приводу дуже складного предмету;

- $\quad$ арт-терапія є засобом переважно невербального спілкування. Це робить ії особливо цінною для тих, хто недостатньо добре володіє мовою, відчуває труднощі в словесному описі своїх переживань, або, навпаки, надмірно пов'язаний із мовним спілкуванням;

творча діяльність у багатьох випадках дозволяє обходити «цензуру свідомості», тому дає унікальні можливості для використовування несвідомих процесів, вираження й актуалізації латентних ідей і станів, тих соціальних ролей, які знаходяться у «витісненому» вигляді або слабко виявлених в повсякденному житті дітей із особливими потребами;

арт-терапевтична робота в більшості випадків викликає у дітей позитивні емоції, допомагає подолати апатію і безініціативність, сформувати активнішу життєву позицію, впевненість у своїх силах, автономність та особистісні риси ; 
- $\quad$ арт-терапія заснована на мобілізації творчого потенціалу дитини 3 особливими потребами, внутрішніх механізмів саморегуляції і зцілення. Вона відповідає фундаментальній потребі в самоактуалізації - розкритті широкого спектру можливостей особистості і ствердження нею свого індивідуально-неповторного способу буття у світі [8, с. 14].

У процесі арт-терапії дитина з особливими потребами отримує можливість пережити болючі для неї ситуації та почати звільнятися від стереотипної поведінки та відношень до оточуючих, які заважають соціальній адаптації. Внаслідок арт-терапевтичної роботи створюються додаткові можливості для внутрішньо-особистісної комунікації, перехід дітей з вадами розвитку на глибші рівні взаємодії з виявом внутрішніх (зокрема неусвідомлюваних) механізмів організації поведінки, відбувається звільнення від упроваджених домінуючою культурою й ідеологією партнерів поведінки і засвоєння тих ролей, що більше відповідають їхній глибинній природі, потребам і напрямкам розвитку. Терапія мистецтвом сьогодні дійсно широко використовується у роботі спеціальних медично-психологічних, соціальних центрах, у спеціальних корекційних дошкільних та шкільних закладах. Таке широке використання арт-терапії мистецтвом у різних типах закладів обгрунтовано властивими ій функціями, а саме: діагностичною, колекційною, розвиваючою, навчальною, реабілітаційною, психотерапевтичною, соціальною та іншими. Крім того, мистецтво своєю образністю активно впливає на свідомість, почуття, волю, грає істотну роль у формуванні культури людини включає в себе художньо-естетичні, гуманістичні, пізнавальні, моральні цінності, впливає на духовно-моральне становлення особистості.

T. Росік зазначає, що музика, театр, танок, живопис, екранні мистецтва сприяють самовираженню само експертними засобами рухів, звуків, письма. Особливо велике значення має мистецтво і художня творчість у житті дитини з функціональними обмеженнями, зокрема 3 порушеннями опорно-рухового апарату й ДЦП. Про це свідчать численні приклади малювання ротом, гри на фортепіано пальцями ніг, вишивання зубами тощо. Конкурси і фестивалі художньої творчості для дітей 3 функціональними обмеженнями демонструють їхній великий потяг до мистецтва, бажання поділитися результатами своєї праці, відчути, що вони спроможні щось зробити самостійно [5, с. 14]. А. Капська додає, що творча діяльність стимулює бажання дітей з особливими потребами спілкуватися, розширювати міжособистісні стосунки. Це один із способів пом'якшити стан відмежованості від інших і запевнити себе в приналежності себе не тільки до певної соціальної групи, а й суспільства в цілому [6, с. 179]. Г. Колесникова підкреслює, що деструктивні стани з'являються як наслідок незадоволення позитивних потреб або їх викривлення, особливо це спостерігається коли дитина з особливими потребами втрачає внутрішню енергію для саморозвитку. Посилюється дискомфорт, що призводить до негативних почуттів i емоцій, а також неконструктивних механізмів психологічного захисту [1, с. 216].

В арт-терапії дітям пропонуються різноманітні заняття образотворчого i художньоприкладного характеру (малюнок, графіка, живопис, скульптура, дизайн, дрібна пластика, різьблення, випалювання, чеканка, гобелен, мозаїка, фреска, вітраж, всілякі вироби з хутра, шкіри, тканин і ін.), які спрямовані на активізацію спілкування з психотерапевтом або в групі в цілому для більш чіткого, тонкого вираження своїх переживань, проблем, внутрішніх суперечностей, з одного боку, а так само творчого самовираження - 3 іншою. У даний час в арт-терапію включаються і такі форми творчості, як відео-арт, інсталяція, перформанс, комп'ютерна творчість, де візуальний канал комунікації відіграє важливу роль. Дієвим засобом психокорекції виступає казкотерапія. Через казку перед дитиною розкриваються глибини іiі власного внутрішнього світу, відбувається знайомство 3 основними психологічними поняттями, розвивається ії індивідуальність. 3 огляду на це вважаємо за доцільне використання казкотерапії у психокорекційній роботі з дітьми, які мають мовленнєві порушення [2, с. 13]. Найбільшого поширення у корекційній роботі з дітьми 3 вадами розвитку набуває терапія засобами зображувальної діяльності (малюнок, ліпка), ефективність якої підтверджена у випадках емоційної депривації, підвищеної тривожності, страхів, неадекватної самооцінки, конфліктних міжособистісних взаємин тощо. За І. П'ятницькою-Поздняковою проведення малюнкової терапії здійснюється арт-терапевтом у формі спеціальних занять, на яких дітям з особливими потребами пропонуються різні завдання. У практиці проведення малюнкової терапії використовують 5 типів завдань [4, с. 40]:

предметно-тематичний тип, в основі зображення якого - людина в іiі взаємодії 3 навколишнім предметним світом і людьми (наприклад, «Моя сім'я», «Моє улюблене заняття»);

образно-символічний тип, що передбачає малювання, пов'язане 3 моральнопсихологічним аналізом абстрактних понять «Добро», «Зло», «Щастя», у вигляді образів, створених уявою дитини, а також зображення емоційних станів та почуттів - «Радість», «Гнів», «Страх» тощо; вправи на розвиток образного сприймання, уяви і символічної функції - завдання, що грунтуються на 
принципі проекції, - «Чарівні плями», а також відтворення у зображенні цілісного об'єкта та його осмислення - «Малювання за крапками»;

ігри-вправи 3 зображувальними матеріалами (фарбами, олівцями, папером, пластиліном тощо), вивчення їх фізичних властивостей та експресивних можливостей - «Малювання пальцями», експериментування 3 кольором (кольоротерапія), пластиліном, тістом (створення найпростіших форм з їх наступним руйнуванням за типом ігор «руйнування- будівництво»);

завдання на спільну діяльність: вони можуть включати завдання попередніх видів, колективне малювання, спрямоване на корекцію проблем спілкування 3 однолітками, покращення стосунків у системі «діти - батьки» $[4$, с. 40].

Музика здавна вважається невербальною формою комунікації, що $є$ більш результативною у сфері почуттів і людських відносин, ніж власне мовне спілкування. Досвід багатьох фахівців нерідко містить приклади використання музики як засобу, що допомагає усунути ізоляцію і створити контакт дитини-інваліда з середовищем, якщо у неї присутні труднощі спілкування з однолітками, коли вона хоче, але не може спілкуватися з іншими дітьми і знаходиться в постійному дисонансі 3 соціумом. Там, де закінчується мова, звучить музика [4, с. 41].

О. Титаренко стверджує, що освоюючи гру на простих музичних інструментах або просто слухаючи музичні твори спільно 3 іншими дітьми, дитина вчитися спілкуватися й отримувати задоволення від спілкування [8, с. 12]. Також під час сприймання музики арт-терапевт допомагає дитині «зробити крок» в уявний світ музичних фарб, таким шляхом звільняючи дитину від негативних переживань. 3 цією метою використовується різноманітна медитативна музика, яка відтворює картини природи: «Спів пташок у лісі», «Світанок у лісі», «Шум дощу». Після прослуховування музичного твору проводиться бесіда 3 дитиною, в якій з'ясовується, що дитина «бачила», «чула», «робила» у такій уявній подорожі. Дослідження показують, що 8-10 цілеспрямованих музично-терапевтичних сеансів значно покращують психоемоційний стан дитини, відволікають її від психотравмуючої ситуації.

Метою лялькотерапії є допомога у ліквідації хворобливих переживань, зміцнення психічного здоров'я, покращення соціальної адаптації, вирішення конфліктів в умовах колективної творчої діяльності. Використання іграшок допомагає зняти агресію, сприяє творчому самовираженню, послаблює негативні емоції. 3 допомогою лялькотерапії (виготовлення ляльки-мотанки, ляльки Тільди) вирішуються такі важливі завдання, як подолання сором'язливості, розширення репертуару самовираження дитини з особливими потребами, досягнення емоційної стійкості і саморегуляції, корекція відносин у системі «батько - дитина». Оскільки світ дитини - це світ дії і діяльності, лялькотерапія дає можливість увійти в цей світ [5, с. 14].

T. Росік виокремлює ще один важливий метод - казкотерапії - використовує казкову форму для мовленнєвого розвитку особистості, розширення свідомості, вдосконалення взаємодії через мову 3 навколишнім світом [5, с. 15]. Основний принцип казкотерапії - цілісний розвиток особистості, турбота про душу (в перекладі з грецької турбота про душу і $є$ терапія). Казка надзвичайно багатогранна, як і саме життя. Спостерігаючи за долями героїв, сприймаючи їх мову, дитина-інвалід навчається вирішувати актуальні для неї в даний віковий період проблеми. За допомогою казки у дітей розвивається уява, мовлення, творчість і виховуються добрі почуття. У системі методів і засобів виховання добрих почуттів казка відіграє не останню роль з багатьох причин: діти люблять героїв, вони стають їм близькими, а значить, можуть і повинні стати прикладом для наслідування [5, с. 16]. Сучасні дослідники (Т. Росік, І. П'ятницька-Позднякова, А. Капська) підкреслюють глибокий соціально-педагогічний потенціал фольклору. За його допомогою можна: регулювати індивідуальну поведінку, співвідносити його з груповою і колективною поведінкою; успішно адаптувати дитину 3 особливими потребами у соціокультурному просторі через прийняття морально-ціннісних норм; знімати соціальну напруженість і протиріччя шляхом моделювання і подолання конфлікту в ігрових формах; активізувати емоційну сферу за допомогою збудження, наслідування і захоплення; досягти психологічної рівноваги з допомогою відчуття розкутості, здатності сміятися над собою, підйому і внутрішнього перетворення на загальному святі. Використання багатого арсеналу засобів фольклору занурює дітей у атмосферу української культури і творчості. Єднання з народним корінням, витоками свого народу веде до емоційної активізації особистості дитини-інваліда, розвитку комунікативних навичок, самореалізації творчих здібностей [7, с. 90].

Висновки 3 даного дослідження і перспективи подальших роздіок. Отже, було теоретично обгрунтовано та експериментально перевірено систему роботи 3 формування комунікативних навичок дітей із особливими потребами засобами арт-терапії, які реалізуються в умовах навчальних закладів та визначають мету, принципи, та зміст, форми в роботі дефектологів. 
Встановлено, що комунікативні навички є засобом здійснення мовленнєвого спілкування. До основних комунікативних навичок можна віднести: активність у спілкуванні, уміння слухати й розуміти мовлення, уміння будувати спілкування з урахуванням ситуації, уміння легко входити в контакт із дітьми й педагогом, зрозуміло та послідовно виражати свої думки, уміння користуватися формами мовленнєвого етикету. Дітям з особливими потребами необхідні такі ж умови для зростання та формування, як і звичайним дітям, вони потребують спілкування й розуміння. Таким малюкам найчастіше не вистачає взаємодії з однолітками, які могли б їх прийняти у своє товариство. Проте соціальна ситуація розвитку дитини 3 особливими освітніми потребами характеризується дефіцитарністю, комунікативне становлення дітей з порушеннями розвитку відбувається не завжди вдало.

Отже, комунікативні навички є засобом здійснення мовленнєвого спілкування. Виявлено, що комунікативні навички й спілкування становлять багатоплановий процес, потрібний для організації контактів між людьми в ході спільної діяльності. 3'ясовано, що представлені техніки арт-терапії при умові використання їх у корекційно-розвивальній роботи 3 дітьми 3 особливими потребами сприятливо впливають на формування у них комунікативних навичок.

\section{Список використаних джерел}

1. Колесникова Г. И. Специальная психология и педагогика / Г. И. Колесникова. -2 -е изд. Ростов на/Д. : Феникс, 2010. -410 с.

2. Підлипишина Л. В. Основи арт-терапії / Л. В. Підлипишина. - Київ : Марич, $2009-60$ с.

3. Полторак Л. Ю. Сутність арт-терапії: аналіз сучасних підходів / Л. Ю. Полторак // Наукові праці Чорноморського державного університету імені П. Могили. Серія: Педагогіка. - 2014. - Вип. 233, т. 245. - C. 89-91.

4. П'ятницька-Позднякова I. С. Арт-терапевтичні можливості видів мистецтва I. С. П'ятницька-Позднякова // Педагогіка : наук. пр. - 2009. - Вип. 95, т. 108. - С. 36-42.

5. Росік Т. Використання технік арт-терапії в соціальній роботі / Т. Росік // Соціальний працівник. - 2007. - № 16. - С. 1-31.

6. Капська А. Й. Соціальна педагогіка : підруч. для студентів вищ. навч. закл. / А. Й. Капська. - Київ : Центр учб. літ., 2011. - 487 с.

7. Сусанина И. В. Введение в арт-терапию : учеб. пособ. / И. В. Сусанина. - М. : КогитоЦентр, 2007. - 95 с.

8. Титаренко O. I. Використання арт-терапії в психолого-педагогічному супроводі освітнього процесу [Електронний ресурс] / О. І. Титаренко // Електронний збірник наукових праць Запорізького обласного інституту післядипломної педагогічної освіти. - Режим доступу: http://virtkafedra.ucoz.ua/el_gurnal/pages/vyp6/tytarenko.pdf.

\section{References}

1. Kolesnikova G. I. Special psychology and pedagogy / G. I. Kolesnikova. - 2nd edition. - Rostov on/D. : Phoenix, 2010. - 410 p.

2. Scriptwriter L. V. Fundamentals of Art Therapy / L. V. Scriptwriter. - Kyyiv : Marich, 2009. $60 \mathrm{~s}$.

3. Poltorak L. Yu. The essence of art therapy: the analysis of modern approaches / L. Yu. Poltorak // Scientific works of P. Mohyly Black Sea State University. Series: Pedagogy. - 2014. - Issue 233, vol. 245. P. 89-91.

4. Pyatnitska-Pozdnyakova I. C. Art-therapeutic possibilities of art / I. C. Pyatnitskaya-Pozdnyakova // Pedagogics: scientific works. - 2009. - Issue 95, vol. 108. - P. 36-42.

5. Rosik T. Use of technique of art therapy in social work / T. Rosick // Social worker. - 2007. - № 16. - P. $1-31$.

6. Cappish A. J. Social pedagogy : under the leadership. for studio higher tutor shut down / A. J. Cappish ; Ministry of Education and Science of Ukraine. - Kyyiv : Center for teaching. L-ry, 2011. $487 \mathrm{p}$.

7. Susanina I. V. Introduction to Art Therapy : A Study Guide / I. V. Susanina. - M. : Kokito Center, 2007. $-95 \mathrm{p}$.

8. Titarenko O. I. Use of art therapy in psychological and pedagogical accompaniment of educational process [Electronic resource] / O. I. Titarenko // The electronic collection of scientific works of the Zaporizhzhya Regional Institute of Postgraduate Pedagogical Education. - Access mode : http://virtkafedra.ucoz.ua/el_gurnal / pages / vyp6 / tytarenko.pdf. 
N.A. Chornous THE ROLE AND PLACE OF ART THERAPY IN THE FORMATION OF COMMUNICATIVE SKILLS OF CHILDREN WITH SPECIAL NEEDS

The article theoretically substantiates the results of experimental verification of the system of work on the formation of communication skills of children with special needs by means of art therapy, which are implemented in the conditions of educational institutions and determine the purpose, principles, and content, forms in the work of defectologists.

The content of the article proves that communication skills are a means of voice communication. It has been revealed that communication skills and communication constitute a multi-faceted process necessary for organizing contacts between people during joint activities. It was found that the presented techniques of art therapy, provided they are used in correctional and developmental work with children with special needs, have a positive effect on the formation of their communication skills.

Key words: children with special needs, art therapy, art therapy techniques, communication skills. 